AHMAR METAKARYA: JURNAL PENGABDIAN MASYARAKAT

Available online at: http://journal.ahmareduc.or.id/index.php/AMJPM

Vol.1, No.2, Februari 2022, Halaman 107-114.

p-ISSN 2807-3797 e-ISSN 2807-3576

\title{
Edukasi Pencegahan Stunting Melalui Pemberian ASI Eksklusif Pada Masyarakat
}

\author{
Dewina Susanti*, Rika Dewi \\ Akademi Kebidanan Saleha, Banda Aceh, Indonesia \\ *E-mail: akbidsaleha akademik@yahoo.com
}

Received: 31 Januari 2022

Accepted: 28 Februari 2022

Published: 28 Februari 2022

\begin{abstract}
Aceh is one of the provinces with the highest prevelance of stunting above the national figure with a stunting prevelance of $37 \%$. During the covid_19 pandemic, the community's space to seek sustenance was hampered, thus affecting the economy to fulfill nutritional sources for children. This activity aims to increase public knowledge about the dangers of stunting and the benefits of exclusive breastfeeding which is rich in nutrition and cheap in stunting prevention. The activities carried out were in the form of educating the benefits of exclusive breastfeeding and the nutrients contained in breast milk as well as demonstrations of Oxytocin massage to facilitate breast milk production for mothers in the community in Meunasah Kulam village, Mesjid Raya district, Kabupaten Meunasah Kulam, Aceh Besar, Aceh Province. The results of this service, mothers can know the importance of exclusive breastfeeding to reduce the incidence of stunting. It is hoped that after public education, especially mothers who have babies and women of childbearing age, husband and wife can apply exclusive breastfeeding to reduce the incidence of stunting.
\end{abstract}

Keywords: Education, Stunting, Exclusive Breastfeeding.

\begin{abstract}
Abstrak
Aceh merupakan salah satu provinsi yang paling besar prevalensi pendek (stunting) diatas angka nasional dengan prevalensi stunting sebesar $37 \%$. Pada masa pandemi Covid-19 ruang gerak masyarakat untuk mencari rezeki terhambat sehingga mempengaruhi ekonomi untuk pemenuhan sumber gizi pada anak. Kegiatan ini bertujuan untuk meningkatkan pengetahuan masyarakat tentang bahaya stunting dan manfaat ASI Eksklusif yang kaya gizi dan murah dalam pencegahan stunting. Kegiatan yang dilakukan berupa edukasi manfaat pemberian ASI Eksklusif dan zat gizi yang terkandung dalam ASI dilanjutkan demonstrasi pijat Oksitosin untuk memperlancar produksi ASI pada Ibu-lbu di desa Meunasah Kulam, Kecamatan Masjid Raya, Kabupaten Aceh Besar Provinsi Aceh. Hasil dari pengabdian ini Ibu-ibu dapat mengetahui pentingnya pemberian ASI Eksklusif untuk mengurangi angka kejadian stunting. Diharapkan setelah dilakukan edukasi masyarakat khususnya ibu yang memiliki bayi dan wanita usia subur, pasangan suami istri dapat menerapkan pemberian ASI Eksklusif guna menekan angka kejadian stunting.
\end{abstract}

Kata Kunci: Edukasi, Stunting, ASI Eksklusif. 


\section{A. PENDAHULUAN}

Stunting adalah masalah kekurangan gizi yang kronis dikarenakan oleh kurangnya asupan gizi dalam jangka waktu yang lama, sehingga mengakibatkan gangguan pertumbuhan pada anak dimana tinggi badan anak lebih rendah atau pendek dari standar usianya. Stunting terjadi akibat kurangnya asupan nutrisi pada bayi bahkan sejak saat masih di dalam kandungan. Menurut WHO, kondisi ini terjadi pada 20 persen kasus kehamilan. Stunting merupakan ancaman utama terhadap kualitas manusia kedepannya, juga ancaman terhadap kemampuan daya saing bangsa. Hal ini dikarenakan anak stunted, bukan hanya terganggu pertumbuhan fisiknya (bertubuh pendek) saja, akan tetapi juga terganggu perkembangan otaknya, yang mana akan mempengaruhi kemampuan dan prestasi dalam pendidikan, produktivitas dan kreativitas. Salah satu pencegahan stunting yang dilakukan oleh pemerintah yakni berfokus pada pendekatan keluarga, karena keluarga merupakan lingkungan pertama yang dikenalkan kepada bayi. Dua tahun pertama kehidupan anak, atau dikenal dengan 1.000 hari pertama adalah masa yang kritis bagi tumbuh kembangnya. Pada waktu inilah bayi harus memperoleh asupan gizi yang cukup dan tepat supaya ia tidak menderita malnutrisi yang dapat berujung pada stunting. Pemberian ASI eksklusif merupakan cara termudah untuk terpenuhinya kebutuhan nutrisi bayi. Manfaat ASI eksklusif telah terbukti membantu anak mendapatkan asupan gizi yang cukup sehingga meminimalisir risiko terjadinya stunting pada anak. Upaya ini bertujuan agar anak-anak Indonesia dapat tumbuh dan berkembang secara optimal dan maksimal, dengan disertai kemampuan emosional, sosial, dan fisik yang siap untuk belajar, serta mampu berinovasi dan berkompetisi dalam bidang apapun (Hizriyani \& Aji, 2021).

Menurut World Health Organization (WHO) (2014) dalam Global Nutrition Targets 2025, stunting dianggap sebagai suatu gangguan pertumbuhan irreversible yang sebagian besar dipengaruhi oleh asupan nutrisi yang tidak adekuat dan infeksi berulang selama 1000 hari pertama kehidupan. Berdasarkan data Riskesdas 2018, kasus stunting di Aceh masih berada di atas angka nasional. Angka stunting di Aceh 37 persen sedangkan nasional 30 persen. Angka ini masih berada di bawah rekomendasi WHO yaitu 20 persen.

Layanan Pengabdian Masyarakat merupakan cara untuk meningkatkan pengetahuan masyarakat tentang bahaya stunting dan meningkatkan kesadaran masyarakat untuk melakukan pemeriksaan tumbuh kembang anak usia balita sebagai skrining sedini mungkin yang dapat menurunkan angka kejadian stunting, tetapi kondisi pandemi turut berpengaruh terhadap layanan kesehatan yang dikarenakan rasa takut dari para ibu terhadap penularan covid 19 yang terjadi saat ini. Oleh karena itu, kegiatan pengabdian kepada masyarakat dilakukan sebagai tindakan pro-aktif untuk memberikan pengetahuan kepada ibu dan masyarakat dalam upaya pencegahan stunting pada anak dengan menumbuhkan kesadaran ibu tentang pentingnya pemberian ASI Eksklusif yang merupakan makanan terbaik bagi bayi di Desa meunasah Kulam Kecamatan Mesjid Raya Kabupaten Aceh Besar. Kegiatan pengabdian masyarakat ini menerapkan protokol kesehatan secara ketat untuk mencegah penyebaran covid-19, pada seluruh tim pengabdian dan peserta sebelum dimulainya kegiatan.

Berdasarkan alasan tersebut, maka tujuan dari dilaksanakannya pengabdian masyarakat ini adalah untuk memberikan edukasi pentingnya pemberian ASI Eksklusif sebagai nutrisi terbaik bagi bayi untuk mencegah angka kejadian stunting pada anak di desa Meunasah Kulam Kabupaten Aceh Besar, hal ini dilakukan sebagai bentuk pengabdian kepada masyarakat.

\section{B. METODE DAN PELAKSANAAN}

Metode yang digunakan dalam pengabdian masyarakat ini yaitu memberikan edukasi melalui penyuluhan tentang pentingnya pemberian ASI Eksklusif dalam upaya mencegah stunting terutama di masa pandemic covid 19 melalui berbagai tahapan, antara lain:

\section{Tahap Persiapan}

Adapun tahapan persiapan (pra planning), pembagian tugas, yaitu antara lain:

a. Mempersiapkan Ruangan / tempat pelaksanaan kegiatan.

b. Mempersiapkan masyarakat dengan mematuhi protokol kesehatan.

c. Melakukan pendataan masyarakat/pasien yang datang berkunjung dengan mengisi daftar hadir. 
d. Melakukan Pengukuran Suhu tubuh..

e. Mempersiapkan alat-alat yang dilakukan dengan prinsip steril,bersih, aman dan nyaman

f. Membuat Pendokumentasian Kegiatan

\section{Tahapan Pelaksanaan}

Sebelumnya dosen pelaksana di bantu oleh mahasiswa memberikan edukasi kepada ibu dan warga masyarakat tentang Stunting dan upaya mencegah stunting dengan asupan makanan bergizi dan pemberian ASI Eksklusif selama 6 bulan setelah itu pemberian ASI sampai usia 2 tahun dengan tambahan makanan pendamping ASI. Kegiatan dilaksanakan selama 1 hari tepatnya pada hari Sabtu, tanggal 15 November 2021 di ikuti oleh 29 orang ibu rentang usia 20-35 tahun yang berdomisili di desa Meunasah Kulam.

\section{Tahap Evaluasi}

a. Struktur

Peserta yang nantinya hadir adalah semua ibu dan warga masyarakat yang berdomisili di wilayah Desa Meunasah Kulam Kecamatan Mesjid Raya Kabupaten Aceh Besar. Setting tempat sudah sesuai dengan rencana yang dibuat dan perlengkapan yang dilakukan untuk pelaksanaan penyuluhan dapat digunakan sebagimana mestinya. Penggunaan Bahasa yang disampaikan saat pemberian penyuluhan sudah komunikatif dalampenyampaiannya, sehingga seluruh ibu dan warga masyarakat memahami materi tentang pentingnya deteksi dini kejadian stunting pada anak sehingga dapat mencegah terjadinya.

b. Proses

Pelaksanaan kegiatan dalam pengabdian masyarakat ini nantinya akan berlangsung selama 1 hari ditanggal 15 November 2021 dari pukul 09.00 s/d 13.00 WIB sesuai jadwal yang telah direncanakan sebelumnya.

c. Hasil

Hasil yang diharapkan terkait penyuluhan dan pelaksanaan pemeriksaan yaitu:

1) Peserta dapat memahami maksud dan tujuan.

2) Peserta dapat memahami latar belakang.

3) Peserta dapat memahami penjelasan tentang deteksi kejadian stunting pada anak.

4) Peserta dapat memahami tentang dampak yang terjadi jika anak mengalami stunting.

\section{HASIL DAN PEMBAHASAN}

Berdasarkan hasil kegiatan pengabdian masyarakat yang dilakukan tentang edukasi pencegahan stunting yaitu edukasi pencegahan stunting pada warga meunasaha Kulam Kecamatan Mesjid Raya Kabupaten Aceh Besar. Kegiatan pengabdian pada masyarakat di Meunasah Kulam Kecamatan Mesjid Raya dilakukan dengan tetap menerapkan protokol kesehatan secara ketat, meskipun masa pandemi sudah mulai normal. Kegiatan ini mendapat sambutan yang baik dari perangkat desa maupun masyarakat. Kegiatan pengabmas yang dilakukan satu hari dimulai dengan memberikan penyuluhan tentang pencegahan stungting (anak pendek) melalui pemberian Asi Ekslusif kepada para bapak-bapak dan ibu-ibu yang hadir. Kemudian setelah tim pengbamas Bersama para mahasiswa yang terlibat dalam memberikan penyuluhan melakukan diskusi tanya jawab seputaran pencegahan stunting. Kegiatan ini sangat berdampak positif bagi masyarakat meunasah Kulam, karena selama ini pemahamam para ibu-ibu bahwa anak pendek itu karena keturunan, padahal terjadinya stunting karena disebabkan oleh berbagai faktor, salah satunya adalah tidak adanya pemberian Asi EKslusif kepada bayi baru lahir. Bahkan kondisi yang sangat memrihatinkan ketika para ibu-ibu dan bapak-bapak di meunasah Kulam selama ini beranggapan bayi lebih baik diberikan susu formula dari pada asi ekslusif.

Berbagai alasan yang dikemukakan oleh ibu-ibu diantaranya, ada sebagian ibu-ibu yang tidak memiliki asi atau kurang asi langsung memberikan susu formula, mengingat lebih aman dari segi waktu tidak perlu berlama-lama memberikan asi. Padahal dari segi ekonomi sangat banyak menghabiskan biaya untuk membeli susu, namun para ibu-ibu memiiki pandangan juga bahwa 
memberi susu formula lebih baik dari pada asi tidak lancar. Kondisi demikian kami tim pengabmas serta mahasiswa bantu mencoba mendemontasikan bagaimana cara memijat payudara untuk menghasilkan asi yang banyak,selain harus didukung dengan makanan yang bergizi, minur air mineral yang banyak selama menyusui, cukup istirahat. Banyak ibu-ibu yang tidak memahami selama ini bahwa efek dari tidak memberikan asi kepada bayi memiliki dampak yang buruk, seperti terjadinya stunting. Ibu-ibu Meunasah Kulam Kecamatan Mesjid Raya kurang memperhatikan tumbuh kembang bayi, karena merasa terlalu banyak habis waktu jika mereka harus memaksa memberikan asi yang tidak lancar, mereka juga merasa tidka bisa mengerjakan pekerjaan rumah jika tiap menit harus memberikan asi. Kondisi tersebut membuat ibu-ibu Meunasah Kulam lebih memilih memberikan susu formula. Kemudian ditemukan juga bahwa ibu-ibu Meunasah Kulam masih banyak yang belum paham Teknik menyusui, sehingga tim mahasiswa mencoba untuk mendemonstrasikan teknik menyusui yang baik dan benar.

Stunting adalah masalah kekurangan gizi yang kronis dikarenakan oleh kurangnya asupan gizi dalam jangka waktu yang lama, sehingga mengakibatkan gangguan pertumbuhan pada anak dimana tinggi badan anak lebih rendah atau pendek dari standar usianya. Stunting terjadi akibat kurangnya supan nutrisi pada bayi bahkan sejak saat masih di dalam kandungan. Menurut WHO, kondisi ini terjadi pada 20 persen kasus kehamilan. Stunting merupakan ancaman utama terhadap kualitas manusia kedepannya, juga ancaman terhadap kemampuan daya saing bangsa. Hal ini dikarenakan anak stunted, bukan hanya terganggu pertumbuhan fisiknya (bertubuh pendek) saja, akan tetapi juga terganggu perkembangan otaknya, yang mana akan mempengaruhi kemampuan dan prestasi dalam pendidikan, produktivitas dan kreativitas. Salah satu pencegahan stunting yang dilakukan oleh pemerintah yakni berfokus pada pendekatan keluarga, karena keluarga merupakan lingkungan pertama yang dikenalkan kepada bayi. Dua tahun pertama kehidupan anak, atau dikenal dengan 1.000 hari pertama adalah masa yang kritis bagi tumbuh kembangnya. Pada waktu inilah bayi harus memperoleh asupan gizi yang cukup dan tepat supaya ia tidak menderita malnutrisi yang dapat berujung pada stunting. Pemberian ASI eksklusif merupakan cara termudah untuk terpenuhinya kebutuhan nutrisi bayi. Manfaat ASI eksklusif telah terbukti membantu anak mendapatkan asupan gizi yang cukup sehingga meminimalisir risiko terjadinya stunting pada anak. Upaya ini bertujuan agar anak-anak Indonesia dapat tumbuh dan berkembang secara optimal dan maksimal, dengan disertai kemampuan emosional, sosial, dan fisik yang siap untuk belajar, serta mampu berinovasi dan berkompetisi dalam bidang apapun(Hizriyani \& Aji, 2021).

Teori lain juga menjelaskan bahwa kejadian stunting dipengaruhi oleh beberapa faktor diantaranya; berat badan saat lahir rendah, asupan gizi balita, pemberian ASI, riwayat penyakit infeksi, pengetahuan gizi ibu balita, dan pendapatan keluarga yang rendah, namun faktor yang paling dominan adalah pemberian ASI. Upaya pemerintah dalam pencapaian penurunan prevalensi stunting melalui program pemberian ASI Eksklusif, namun dalam pelaksanaan ASI eksklusif menemui beberapa hambatan yaitu tersedianya susu formula, ibu menyusui yang bekerja dan kemampuan teknik menyusui serta rasa percaya diri yang kurang. ASI tidak dapat diganti dengan susu formula dalam kondisi apapun namun karena harus bekerja maka sulit memberikan ASI eksklusif. Oleh karena itu perlunya memberdayakan Kader Kesehatan untuk mendampingi dan melakukan advokasi agar ASI tetap diberikan meski ibu bekerja (Ritonga, 2021).

Stunting adalah gangguan pertubuhan dan perkembangan otak pada anak yang di sebabkan karena kekurangan asupan gizi dalam waktu lama, infeksi yang berulang, dan kurangnya stimulasi psikososial. stunting adalah masalah gizi utama yang akan berdampak pada kehidupan sosial dan ekonomi dalam masyarakat. Selain itu stunting dapat berpengaruh pada anak balita pada jangka panjang yaitu menganggu kesehatan, pendidikan serta produktifitasnya di kemudian hari. Anak balita stunting cenderung akan sulit mencapai potensi pertumbuhan dan perkembangan yang optimal baik secara fisik maupun psikomotorik. Stunting adalah penyakit yang disebabkan oleh kekurangan gizi kronis pada masa awal kehidupan anak (Purwanti, dkk, 2019).

Stunting adalah permasalahan gizi kronis yang disebabkan oleh kurang nya asupan gizi dalam waktu yang cukup lama, sehingga mengakibatkan gangguan pertumbuhan pada anak yaitu tinggi badan anak yang lebih rendah atau lebih pendek (kerdil) dari standar usianya. Stunting juga didenisikan sebagai keadaan dimana balita memiliki panjang atau tinggi adan yang kurang ika dibandingkan dengan umur. Keadaan ini di ukur dengan panjang atau tinggi badan yang lebih dari 
minus dua standar deviasi median standar pertumbuhan anak dari WHO. Balita yang menderita stunting termasuk masalah gizi kronik yang disebabkan oleh banyak faktor seperti kondisi social ekonomi, gizi ibu saat hamil, kesakitan pada bayi, tidak adanya pemberian asi ekslusif dan kurangnya asupan gizi pada bayi (Kurniati, 2020)

Menurut beberapa hali mengatakan bahwa stunting disebabkan oleh faktor multi dimensi dan tidak hanya disebabkan oleh faktor gizi buruk. Secara lebih detil, terdapat beberapa faktor yang menjadi penyebab stunting, yaitu: adanya praktek pengasuhan yang kurang baik, seperti kurangnya pengetahuan ibu mengenai kesehatan dan gizi sebelum dan masa kehamilan, serta setelah ibu melahirkan. Kurangnya pemberian ASI kesklusif pada anak usia 0 - 6 bulan dan kuangnya pemberian makanan pendamping ASI pada anak usia $0-24$ bulan. MP - ASI diberikan ketika balita berusia di atas 6 bulan. Kemudian masih terbatasnya layanan kesehatan termasuk layanan ANC Ante Natal Care, Post Natal Care dan pembelajaran dini yang berkualitas. Masih kurangnya akses rumah tangga / keluarga ke makanan bergizi dan kurangnya akses ke air bersih dan sanitasi (Kurniati, 2020).

Selain faktor di atas prevalensi stunting pada balita menurut umur, tampak bahwa prevalensi stunting naik terus dari usia 6 bulan $(22,4)-1$ tahun $(27,3)-2$ tahun $(36,1)-3$ tahun $(40,9$ tertinggi), untuk kemudian turun sedikit menjadi 38,7 pada usia 5 tahun ini jelas terjadi prevalensi pendek artinya selama perjalanan sampai usia 5 tahun terjadi gangguan sehingga stunting justru bertambah. Jika dikaitkan dengan laju pertumbuhan WHO bahwa baik balita laki-laki maupun perempuan makin menjauh / melebar dan terjadi perlambatan pertumbuhan. Banyak faktor yang menyebabkan hal ini terjadi, namun karena mereka sangat tergantung pada ibu/keluarga, maka kondisi keluarga dan lingkungannya yang mempengaruhi keluarga akan berdampak pada status gizinya. Pengurangan status gizi terjadi karena asupan gizi yang kurang dan sering terjadinya insfeksi. Jadi faktor lingkungan, keadaan dan perilaku keluarga yang mempermudah insfeksi berpengaruh pada status gizi balita. Kecukupan energi dan protein per hari perk kapita anak Indonesia terlihat sangat kurang jika dibandingkan Angka Kecukupan Gizi (AKG) yang dianjurkan baik pada anak normal atau stunting(Trihono, 2015).

Hasil penelitian yang diungkapkan oleh Ahmed, dkk (2021) dengan judul Pemetaan Perbedaan Geografis dan Penelitian Faktor Penentu Stunting pada Anak di Ethiopia: Sebuah Analisa Geostatistik Bayesian. Studi ini meneliti tentang variasi geografis terkait dengan prevalensi stunting di tingkat sub-nasional, dan faktor penentu stunting pada anak di bawah usia 5 tahun di Ethiopia. Peneliti menggunakan dataset terkait anak-anak berusia 0-59 bulan dengan pengukuran antropometrik dan koordinat geografis yang valid $(n=9089)$ yang berasal dari Survei Demografi dan Kesehatan Ethiopia (EDHS) tahun 2016. Peneliti memodelkan prevalensi stunting dan faktor penentunya dengan menggunakan model regresi eksplisit geospasial Bayesian. Prevalensi stunting pada anak di bawah lima tahun di Ethiopia adalah 36,3\% (95\% interval kredibel (Crl); 22,6\%, 51,4\%) dengan variasi yang luas di tingkat sub-nasional dan berdasarkan kelompok umur. Prevalensi stunting pada anak berkisar antara 56,6\% (37,4-74,6\%) di zona khusus Mekelle di wilayah Tigray hingga 25,5\% (10,5-48,9\%) di zona Sheka di wilayah SNNPR. Faktor-faktor yang terkait dengan penurunan kemungkinan stunting di Ethiopia terdiri dari tidak adanya ASI, indeks massa tubuh ibu (yaitu kelebihan berat badan/obesitas), status pekerjaan (bekerja), dan kesejahteraan rumah tangga yang lebih tinggi, sedangkan yang menjadi faktor yang memungkinkan munculnya stunting adalah bertempat tinggal di wilayah geografis yang "kering", berat bayi lahir rendah, dan indeks massa tubuh ibu (yaitu berat badan kurang). Prevalensi dan faktor penentu stunting bervariasi di seluruh Ethiopia. Upaya yang dilakukan untuk mengurangi angka stunting pada anak harus mempertimbangkan keberagaman geografis ini dan faktor-faktor risiko lainnya yang dapat dimodifikasi.

Stunting perlu dicegah sedini mungkin agar generasi nanti dapat menjadi lebih sehat. Stunting atau pendek merupakan kondisi gagal tumbuh pada bayi ( 0 - 11 bulan ) dan anak balita ( $12-59$ bulan ) akibat dari kekurangan gizi kronis terutama dalam 1.000 hari pertama kehidupan sehingga anak menjadi terlalu pendek untuk usianya. Kekurangan gizi yang terjadi sejak bayi dalam kandungan dan pada masa awal setelah bayi lahir akan terlihat setelah anak berusia 2 tahun (Persatuan Ahli Gizi Indonesia, 2018 ). 
Adapun beberap dokumentasi dari kegiatan pengabdian masyarakat mengenai edukasi pencegahan stunting di Meunasah Kulam Kecamatan baiturrahman Kabupaten Aceh Besar di bawah ini.

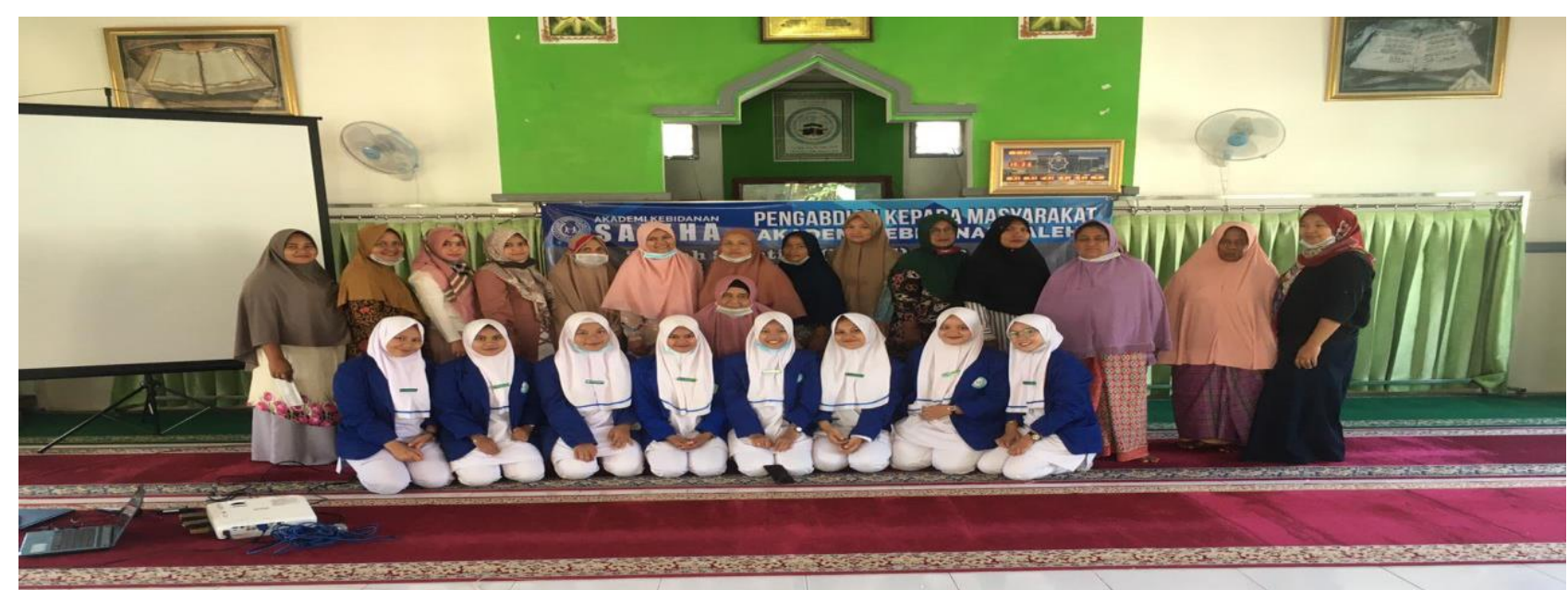

Gambar 1. Foto bersama para ibu-ibu yang mengikuti edukasi stunting di meunasah Kulam Kabupaten Aceh Besar

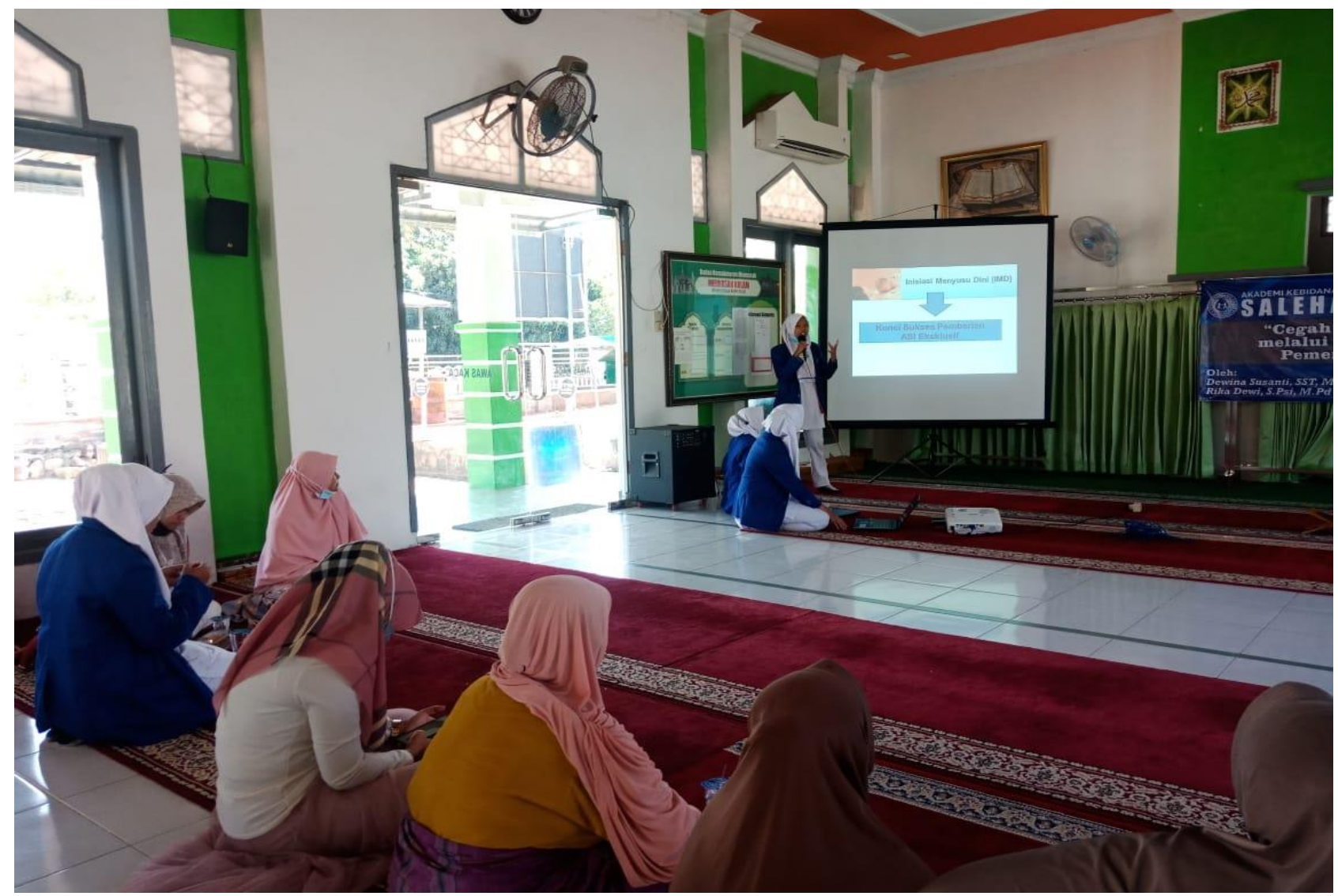




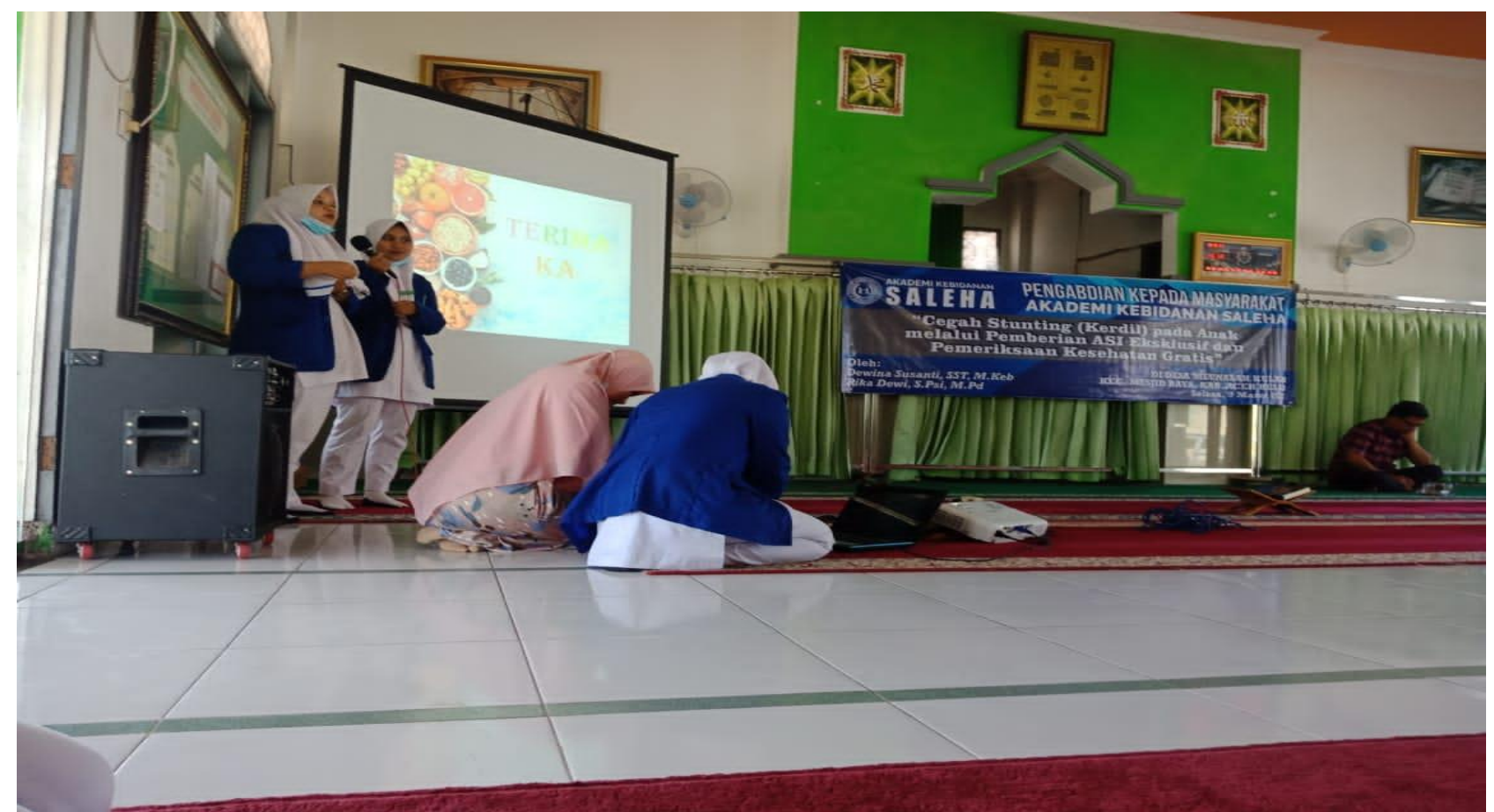

Gambar 2. Mahasiswa sedang memandu sesi tanya jawab bagi ibu-ibu yang mau bertanya tentang materi stunting, Dosen juga siap memberikan arahan tambahan bagi para warga Meunasah Kulam Kabupaten Aceh Besar.

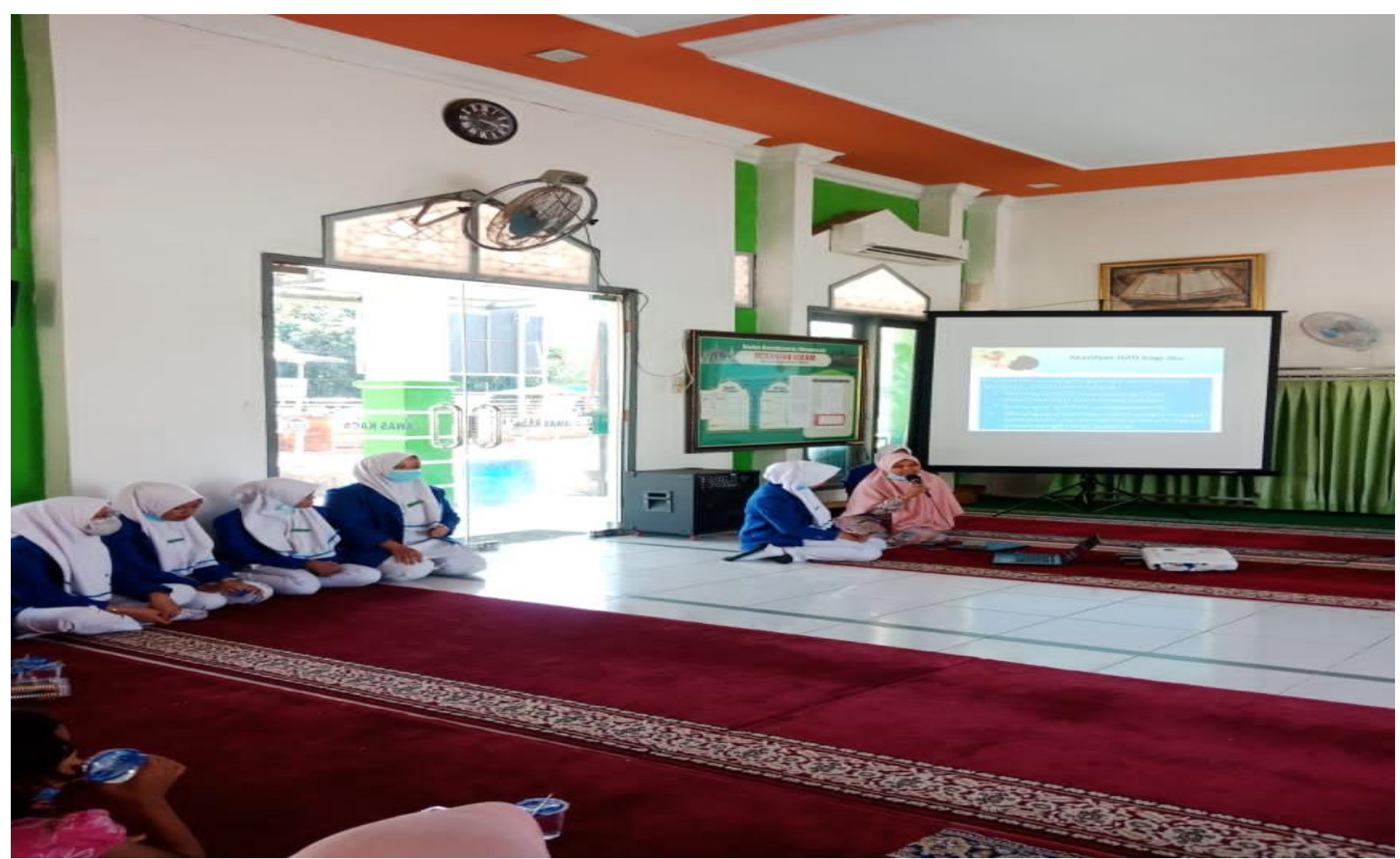

Gambar 3. Dosen sedang memberikan penjelasan mengenai berbagai alternative yang dapat mencegah stunting dan dampak dari stunting itu bagi anak. 


\section{KESIMPULAN}

Kegiatan pengabdian pada masyarakat Meunasah Kulam Kecamatan Mesjid Raya "Edukasi Pencegahan Stunting Melalui Pemberian Asi Ekslusif" berjalan lancar dan diikuti dengan antusias ibu-ibu semua yang berjumlah 29 orang. Setelah dilakukan kegiatan edukasi pencegahan stunting didapatkan bahwa warga Meunasah Kulam sudah memahami tentang penyebab terjadinya stunting pada anak, selanjutnya ibu-ibu baru mengetahui bahwa untuk menghasilkan asi yang lancar harus dengan Teknik pemijatan payudara dan konsumsi makan yang bergizi agar bayi dapat diberikan Asi secara ekslusif.

\section{UCAPAN TERIMA KASIH}

Ucapan terima kasih yang sebesar-besarnya kami sampaikan kepada para Camat, Kapolsek, Puskesmas , Kepala Lurah Meunasah Kulam dan para masayarakat desa Meunasah Kulam Kecamatan Mesjid Raya Kabupaten Aceh Besar yang telah memberikan izin dan dukungan terhadap pelaksanaan kegiatan pengabdian masyarakat. Kepada warga meunasah Kulam terima kasih atas partisipasinya semua selama kegiatan bapak-bapak dan ibu-ibu semua maupun remaja masjid Meunasah Kulam yang sudah hadir pada saat kegiatan berlangsung. Terima kasih juga kami ucapakna kepada Kepala Lurah dan Perangkat desa semua atas fasilitas yang diberikan kepada Akbid Saleha Banda Aceh sehingga kegiatan pengabdian masyarakat ini berlangsung dengan lancar.

\section{DAFTAR PUSTAKA}

Ahmed, K. Y., Agho, K. E., Page, A., Arora, A., \& Ogbo, F. A. (2021). Mapping Geographical Differences and Examining the Determinants of Childhood Stunting in Ethiopia: A Bayesian Geostatistical Analysis. Nutrients, 13(6), 2104. https : // doi. org/ 10.3390/ nu13062104 Purwanti, R., \& Nurfita, D. (2019). Review Literatur: Analisis Determinan Sosio Demografi Kejadian Stunting Pada Balita di Berbagai Negara Berkembang. Buletin Penelitian Kesehatan, 47(3), 153-164.

Kurnia. T. P. (2020). Stunting dan Pencegahannya. Yogyakarta: Penerbit Lakeisha.

Hizriyani, R. \& Aji, T. S. (2021). Pemberian Asi Ekslusif Sebagai Pencegahan Stunting. Jurnal Jendela Bunda Program Studi PG-PAUD Universitas Muhammadiyah Cirebon, 8(2), 55-62.

Persatuan Ahli Gizi Indonesia. (2018) Penuntun Konseling Gizi. Jakarta: Penerbit PT. Abadi.

Ritonga, F. (2021). Hubungan Karakteristik Dan Motivasi Ibu Dengan Efektifitas Asi Eksklusif Di Rumah Sakit Umum Imelda Pekerja Indonesia Tahun 2019. Jurnal IImiah Kebidanan Imelda, 7(2). https://doi.org/10.52943/jikebi.v7i2.631

Trihono. (2015). Pendek (Stunting) di Indonesia, Masalah dan solusinya. Balitbangkes.

WHO. (2014). Health for the World's Adolescents: A Second Chance in the Second Decade. Geneva: World Health Organization. 